\title{
WATER-CONTACT PATTERNS AND SCHISTOSOMA MANSONI INFECTION IN A RURAL COMMUNITY IN NORTHEAST BRAZIL (1)
}

\author{
Eduardo MOTA (2) \& Adrian C. SLEIGH (3)
}

\section{S U M M A R Y}

We evaluated the influence of water-related human activities, contaminative behaviour, house location, education and socio-economic status on endemic Schistosoma mansoni infection. The study was conducted in a hilly non-irrigated area of rural northeast Brazil amongst a defined population of subsistence farmers. of whom $93 \%$ were infected by age 20 . The area was mapped, water bodies were surveyed, and a detailed questionnaire was performed on each household. Infection was assessed by duplicate stool examinations using the sensitive Bell technique to quantify egg excretion. For each household, and index of intensity of infection was computed by grouping individual log-transformed egg counts as an age-sex adjusted $\mathbf{Z}$ score. Few households had a sanitary installation or a domestic water supply. However, neither water-contact nor contaminative behavior were indiscriminate. The people made considerable effort to defaecate far from a water source, to obtain household drinking water from the cleanest source, and to bathe only at certain sites where privacy is assured. Land ownership and literacy correlated poorly with the household index of intensity of infection. The key influence on infection status was the relative location of the house and snail-free or snail colonized water sources. In this area, a safe domestic water supply is the critical input needed to achieve definitive control of endemic Schistosomiasis.

KEY WORDS; Schistosoma mansoni - infection; Schistosomiasis

- rural community; Transmission - water contact.

\section{NTROD U CTION}

It is known that transmissions of $\mathbf{S}$. mansoni in an endemic area depends on a number of interrelated socioecological variables that determine human water contact behaviour, faecal contamination of water sources and the presence of suitable snail hosts $3,5,6,17$. In this study, an attempt has been made to quantify the relative importance of the socio-economic determinants of house location, education and water-related human activities, in the distribution of the prevalence and intensity of infection in a population of an endemic area in the state of Bahia, Brazil.

(1) Presented at the XVI Congresso da Sociedade Brasileira de Medicina Tropical, Natal, Rio Grande do Norte, Brazil, 3-8 February, 1980

(2) Departamento de Medicina Preventiva, Faculdade de Medicina, Universidade Federal da Bahia. Rua Padre Feijó, 29 - 4.0 andar, Canela. 40000 Salvador, Bahia, Brasil

(3) Department of Tropical Public Health, Harvard school of Public Fealth; Boston, Massachusetts, USA

The Harvard component was directed by Dr. Thomas $H$. Weller and was supported by grants from the Wellcome Trust and the Edna McConnel Clark Foundation. Field activities were performed in collaboration with Fundacão Os. waldo Cruz (FIOCRUZ) and were supervised in Bahia by Dr. Italo Sherlock. Subsidiary grants were received from the Pan American Health Organization and Indústria $\theta$ Comércio de Mineraça S.A. (ICOMI) 
MOTA, E. \& SLEIGH, A. C. - Water-contact patterns and Schistosoma mansoni infection in a rural community in Northeast Brazil. Rev. Inst. Med. trop. São Paulo, 29(1): 1-8, 1987.

This report forms part of a long term pro. ject aimed at improving our knowledge of the epidemiology and control of Manson's schistosomiasis. The project extended from 1974 to 1984 and was conducted in the municipality of Castro Alves, an area typical of peasant farm. ing communities of the litoral of Northeast Brazil 2,10,11,14,15,18-20. This study provides back. ground data on the life circumstances and constraints that relate to endemic Schistosomiasis, together with its implications for promotion of long term control of the disease.

\section{MATERIALS AND METHODS}

\section{Study Area and Population}

The study area included three contiguos fazendas (geopolitical units) called Morro do Afonso, Graviel and Riacho Seco (figure 1), which 'were mapped in 1973 16. A census of the resident population was conducted annually from 1974 to 1983.

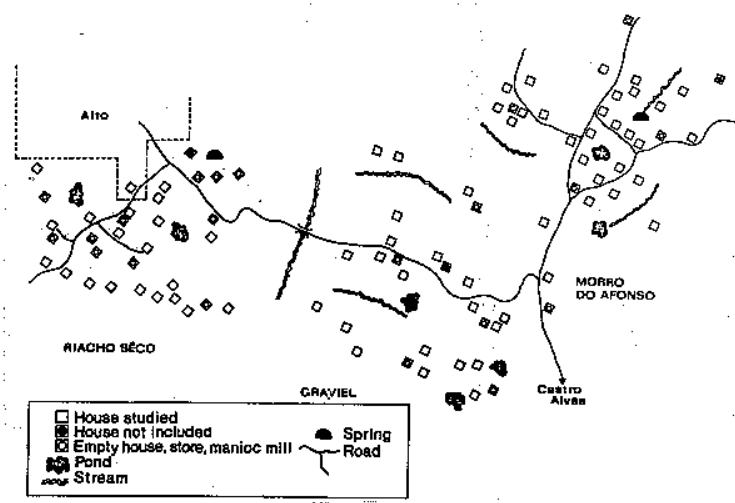

Fig. 1 - Map showing houses and snail habitats in Fazendas Morro do Afonso, Graviel and Riacho Seco in the Castro Alves Study area, Bahia, Brazil.

The area includes 25 square $\mathrm{Km}$; the lati. tude is $12^{\circ} 45^{\prime} 36^{\prime \prime} \mathrm{S}$ and the longitude is $39^{\circ} 25^{\prime}$ 43"W. The terrain is hilly and temperatures range from 17 to $20^{\circ} \mathrm{C}$ at night to 26 to $35^{\circ}$ during the day. Rainfall varies from 130 to $180 \mathrm{~cm}$ annually with most occurring from April to August ${ }^{11}$.

Virtually all families are engaged in nonmechanized farming of manioc as the staple and tobacco as a cash crop. There is no irrigation. The houses are dispersed along the ridges and are usually nearby the family plots on the hill slopes. Water is available only from small streams, ponds and springs in the valleys except for the few families with storage tanks for rainwater. Most valleys are fenced off for cattle farming.

\section{Household Survey}

A questionnaire, after pre-testing, was carried out in June 1978 by a Bahian physician (E.M.) well known in the area. The survey included 69 of the 72 households; one or more of the adults, usually females, provided the information for each family. Each of the three househoids not contactable had one occupant only. For each household information was obtained on domestic water use (source, storage, treatment before use) water contact (site, duration, frequency and time of day of bathing and clothes-washing) sanitary practices (usual place of defaecation) and domestic hygiene (household cleaning, garbage disposal). Information was also obtained on socio-economic structure (house size and construction, number, age and sex of residents, family assets, farming activities, income and landownership status) and education (number of years of schooling and graded assessment of ability to read and write for each individual). Each fa. mily interview lasted 45 minutes to one hour. All responses were numerically coded, to facilftate subsequent analysis.

\section{Water Survey}

Using standard sampling methods for snail surveys 16 each waterbody identified in the area in January 1980 was examined once for the presence of Biomphalaria spp. The only speciesfound within this study area was B. glabrata although uninfected $\mathbf{B}$. straminea has been detected in a nearby area during detailed mala cological surveys of Castro Alves ${ }^{15}$.

\section{Faecal Examinations}

Specimens were collected and processed by a modification of the Bell method II. Egg counts from duplicate papers were averaged for each stool sample. Individual infection was defined by the detection of $\mathbf{S}$. mansoni eggs in the faecal sample, and the intensity of in. fection was estimated by the egg count. We 
MOTA, E. \& SLEIGH, A. C. - Water-contact patterns and Schistosoma mansoni infection in a rural community Jn Northeast Brazil. Rev. Inst. Med. trop. Sī̃ Paulo, 29(1): 1-8, 1987.

used data from an earlier stool survey (April 1977) because the population had been treated with oxamniquine18. These pre-treatment egg counts provided information on the "natural" intensity of infection. It is unlikely that the local ecology, behaviour or socio-economic structure changed over the 14 month period between the stool survey and the questionnaire.

\section{Data Analysis}

When appropriate individual data were aggregated by gender, age group, graded intensity of infection, household and house lo. cation. The level of data aggregation chosen for each analysis reflected the level of impact of the variable under consideration. Thus the impact on the intensity of $\mathbf{S}$. mansoni infection of the variable under consideration. Thus the analysed by individual or age-sex aggregated data, whereas the impact of the physical environment, socio-economic status or education were analysed by household aggregated data: The prevalence of infection for individuals in various age-sex groups was calculated.

As the intensity of $\mathbf{S}$. mansoni infection varies with age the age structure of a family will influence the mean intensity of infection for that household. Fence, to enable valid comparisons, a household index of infection was created by calculating age sex specific $Z$ scores using logarithms of egg counts. The score was computed using standard methods whereby egg count values were corrected by subtracting the population mean egg count for the age and sex group from the observed hou. sehold age and sex specific mean egg count and dividing the difference by the standard deviation of egg count within the corresponding age and sex group $(\mathrm{z}=\mathrm{X} \cdot \overline{\mathrm{X}}) / \mathrm{SD})$. The household index of infection was the sum of age-sex specific $Z$ scores for the household. If a $Z$ score is zero, then that family's value is equal to the expected mean for the population age-sex strata represented within that household. A positive or negative $\mathbf{Z}$ score indicates a value that is greater than or less than the mean, respectively. Household indices of infection varied from $-3.82+1.26$ mean standard deviation

Socio-economic status (land-ownership, assets and income) was compared to the house- hold index of infection. Literacy was defined as the ability to read and write a message. The prevalence of literacy and the average amount of schooling were compared for adults ( $>15$ years old) and children. The household indices of infection were contrasted for those families with zero and with one literate person. House construction, size, crowding, sanitary installation, defaecation practices and garbage disposal were described.

The source of domestic water used for drinking was compared to the source of water used for home bathing. The existence of perceived alternative sources was compared to the potential sources documented by the water survey. The median time spent fetching water per day was compared to the average amount of water stored for each household.

Data on individual water contact due to bathing outside the house were agregated into two age groups ( $\leq 15$ and $>15$ years) and the average time spent for outside bathing was then calculated for each group by the average weekly frequency. Data on individual water contact due to clothes washing were analysed by age, sex, location, duration and time of day. Water contact due to playing was not quantified by this study.

\section{RESULTS}

\section{Prevalence and Intensity of S. mansoni Infec- tion}

The overall prevalence of $\mathbf{s}$. mansoni infection was $71.1 \%$ and was similar to that noted in the 1974 survey of the same population:11. The prevalence and intensity of infection rose rapidly after five years of age (Table 1). Over $93 \%$ of individuals were infected by age 20. Individuals aged $\mathbf{1 5 - 2 5}$ years were particularly prone to heavy infections; thereafter the prevalence and intensity of infection in ol. der individuals began to decline.

\section{Housing and Hygiene}

Housewalls were constructed of mud and wattle $(75 \%)$ or adobe $(25 \%)$ and roofs of locally produced clay tiles $(60 \%)$ or thatch (40\%). Most houses had mud floors, two bedrooms and an occupancy of five persons. Do- 
MOTA, E. \& SLEIGH, A. C. - Water-contact patterns and Schistosoma mansonl infection in a rural community in Northeast Brazil. Rev. Inst. Med. trop. Sifo Paulo, 29(1): 1-8, 1987.

T A B L E I

Prevalence and intensity of S. mansoni infection in the study population, Castro Alves, Bahia, 1978

\begin{tabular}{|c|c|c|c|c|c|}
\hline $\begin{array}{c}\text { Age } \\
\text { (years) }\end{array}$ & Sex & $\begin{array}{l}\text { Total } \\
\text { resident } \\
\text { population * }\end{array}$ & $\begin{array}{l}\text { Number } \\
\text { with } \\
\text { stool } \\
\text { exam. * * }\end{array}$ & $\begin{array}{l}\text { Prevalence } \\
\text { of } \\
\text { infection } \\
\quad \%\end{array}$ & $\begin{array}{l}\text { Geometric } \\
\text { mean - } \\
\text { Eggs Per: } \\
\text { Gram }\end{array}$ \\
\hline \multirow[t]{2}{*}{$<1$} & M & 17 & 3 & 33.3 & 5 \\
\hline & $\mathbf{F}$ & 21 & 9 & 33.3 & 18 \\
\hline \multirow[t]{2}{*}{1.4} & $M$ & 26 & 24 & 45.8 & 24 \\
\hline & $F$ & 20 & 18 & 38.8 & 21 \\
\hline \multirow[t]{2}{*}{$5-9$} & $\mathbf{M}$ & 24 & 23 & 65.2 & 112 \\
\hline & $\mathbf{F}$ & 30 & 26 & 65.3 & 67 \\
\hline \multirow[t]{2}{*}{$10-14$} & $\mathbf{M}$ & 30 & 20 & 80.0 & 72 \\
\hline & $F$ & 19 & 18 & 83.3 & $10 \mathrm{i}$ \\
\hline \multirow[t]{2}{*}{$15-19$} & $\mathbf{M}$ & 7 & 6 & 66.6 & 183. \\
\hline & $\mathbf{F}$ & 16 & 12 & 91.6 & 169 \\
\hline \multirow[t]{2}{*}{$20-24$} & $\mathbf{M}$ & 9 & 4 & 75.0 & 212 \\
\hline & $F$ & 12 & 11 & 100.0 & 111 \\
\hline \multirow[t]{2}{*}{$25-34$} & $\mathbf{M}$ & 21 & 17 & 82.3 & 70 \\
\hline & $\mathbf{F}$ & 23 & 23 & 86.9 & 89 \\
\hline \multirow[t]{2}{*}{$35-44$} & $\mathbf{M}$ & 12 & 11 & 81.8 & 92 \\
\hline & $F$ & 23 & 22 & 86.3 & 77 \\
\hline \multirow[t]{2}{*}{$45-54$} & $M$ & 14 & 12 & 75.0 & 59 \\
\hline & $F$ & 8 & 4 & 100.0 & 100 \\
\hline \multirow[t]{2}{*}{$55-64$} & $\mathbf{M}$ & 9 & 9 & 77.7 & 21 \\
\hline & $F$ & 9 & 9 & 77.7 & 96 \\
\hline \multirow[t]{2}{*}{$65+$} & $\mathbf{M}$ & 15 & 14 & 64.2 & 59 \\
\hline & $\mathbf{F}$ & 11 & 10 & 50.0 & 43 \\
\hline \multirow[t]{2}{*}{ Total } & $\mathbf{M}$ & 174 & I43 & 68.5 & \\
\hline & $F$ & 192 & 162 & 73.5 & \\
\hline
\end{tabular}

* Population based on the annual census October 1977

* * April 1977 stool survey. Stool examined by Bell technique $\mathrm{M}=$ male, $\mathrm{F}=$ female

mestic garbage was usually thrown on the house as fertilizer for fruit trees or as food or domestic animals. No composting was done. Only five households had sanitary installation of which four were it privies; the rest of the population defaecate on the ground usually at a specific site near the house. The defaecation site was a sensitive subject and was not pursued further for this survey.

\section{House Location, Land-ownership, Education and Infection}

The best predictor of the household infection index was house location (Table 2). Mo. reover, households from fazenda Morro do Afonso (Figure 1) had a mean infection index $(-0.75)$ substantially lower than the mean infection index for fazendas Graviel and Riacho Seco combined $(+0.17)$. Land-ownership was a poor predictor of household infection indices (an average of $\mathbf{- 0 . 4 8}$ for families owning land and -0.33 for those that did not) and this observation held true when comparing landowning and non-landowning families living on the same fazenda.

We found that $30 \%$ of adults and $22 \%$ of school-age children were literate. The mean indices of infection for the 41 families with one or more literature persons and for the 28 families with no literate persons were similar (infection indices of -0.10 and -0.36 , respectively).

\section{Water Use Inside the House}

Water is usually fetched by adolescents and female adults. For drinking water, $81 \%$ (56/69) of families used the spring and only $38 \%$ reported an alternative source, including the 21 families who collected rain water to supplement supplies (Table 3). Infants and 
MOTA, E. \& SLEIGH, A. C. - Water-contact patterns and Schistosoma mansoni infection in a rural community in Northeast Brazil. Rev. Inst. Med. trop. São Paulo, 29(1): 1-8, 1987.

T A B L E II

Varfation of the Age-especific prevalence and intensity of $\mathbf{S}$. mansoni infection according to household location within the study area

\begin{tabular}{|c|c|c|c|c|c|c|c|c|c|}
\hline \multirow[b]{3}{*}{$\begin{array}{c}\text { AGE } \\
\text { (years) }\end{array}$} & \multicolumn{9}{|c|}{ Place of residence } \\
\hline & \multicolumn{3}{|c|}{ Morro do Afonso } & \multicolumn{3}{|c|}{ Graviel } & \multicolumn{3}{|c|}{ Racho seco } \\
\hline & $\begin{array}{l}\text { N.o with } \\
\text { stool } \\
\text { exam. }\end{array}$ & $\begin{array}{c}\text { Prevalence } \\
\text { of infection } \\
\%\end{array}$ & $\begin{array}{l}\text { Egg } \\
\text { count * }\end{array}$ & $\begin{array}{l}\text { N.o with } \\
\text { stool } \\
\text { exam. }\end{array}$ & $\begin{array}{c}\text { Prevalence } \\
\text { of infection } \\
\%\end{array}$ & $\begin{array}{l}\mathrm{Egg} \\
\text { count * }\end{array}$ & $\begin{array}{l}\text { N.o with } \\
\text { stool } \\
\text { exam. }\end{array}$ & $\begin{array}{c}\text { Prevalence } \\
\text { of infection } \\
\%\end{array}$ & $\begin{array}{l}\text { Egg } \\
\text { count }\end{array}$ \\
\hline 0.4 & 19 & 21.1 & li & 21 & 57.1 & 34 & 14 & 42.9 & 10 \\
\hline $5 \cdot 14$ & 42 & 52.4 & 25 & 25 & 92.0 & 145 & 21 & 90.5 & 205 \\
\hline $15-34$ & 32 & 75.0 & 35 & 23 & 100 & I34 & 21 & 90.5 & 114 \\
\hline $35 \dot{+}$ & 36 & 63.9 & 27 & 27 & 88.9 & 61 & 29 & 79.3 & 146 \\
\hline Total & 129 & 56.6 & - & 96 & 85.4 & - & 85 & 78.8 & - \\
\hline
\end{tabular}

* Geometric mean egg count or those nected (eggs er gram)

T A B L E III

Number of families according to source of water used at home

\begin{tabular}{|c|c|c|c|c|c|c|c|c|}
\hline \multirow{3}{*}{$\begin{array}{l}\text { Source } \\
\text { of } \\
\text { water }\end{array}$} & \multicolumn{4}{|c|}{ Drinking } & \multicolumn{4}{|c|}{ Bathing } \\
\hline & \multicolumn{2}{|c|}{$\begin{array}{l}\text { First } \\
\text { source }\end{array}$} & \multicolumn{2}{|c|}{$\begin{array}{l}\text { Second } \\
\text { source }\end{array}$} & \multicolumn{2}{|c|}{$\begin{array}{l}\text { First } \\
\text { source* }\end{array}$} & \multicolumn{2}{|c|}{$\begin{array}{l}\text { Second } \\
\text { source }\end{array}$} \\
\hline & N.o & \% & N.o & $\%$ & N.a & $\%$ & $\mathrm{~N} . \mathrm{a}$ & $\%$ \\
\hline Spring & 56 & 81.2 & 4 & 5.8 & 28 & 40.6 & 2 & 2.9 \\
\hline Pond & 5 & 7.2 & 1 & 1.5 & 1 & 1.5 & 2 & 2.9 \\
\hline Stream & 4 & 5.8 & 0 & - & 33 & 47.8 & 1 & 1.5 \\
\hline $\begin{array}{l}\text { Rain } \\
\text { No aiternative }\end{array}$ & 4 & 5.8 & 21 & 30.4 & 5 & 7.2 & 15 & 21.7 \\
\hline source & $\ldots$ & - & 43 & 62.3 & - & 一 & 49 & 71.0 \\
\hline
\end{tabular}

* Information was not available for two families.

the elderly usually bathed at home, using water most often (48\%) fetched from streams. Again, few families (29\%) reported an alternative source, and 15 families collected rainwater as a secondary source. Fifty seven percent $(13 / 23)$ of the families using spring water for both drinking and bathing at home lived near a spring, i.e. on fazenda Morro do Afonso.

Water for domestic use was stored in clay, tin or wooden jars. The median time per day spent fetching water was 20 minutes for the households (38\%) storing a one day supply of water, 30 minutes for those $(35 \%)$ storing a two day supply and 35 minutes for families (27\%) with water stored for a period longer than 48 hours. Only four families boiled and $12(17 \%$ ) filtered water before drinking it. The filters used for this purpose are of unknow efficacy.

Five families had recently spent US\$120180.00 each to build large brick and cement tanks $(5000-15000$ liters) to store rainwater captured from the house roof. They reported that the tanks stored enough water, to supply domestic needs during the drier months. These families were all landowners and lives in houses with tiled roofs.

\section{Water-Contact Outside the House}

The adult and adolescent female population spent and average of six hours sach time they washed clothes, usually in streams twice a week. The preferred time was $10 \mathrm{am}$ to $4 \mathrm{pm}$. The young children often jlayed in the water at this time. Overall, $64 \%$ of the total population bathed outside the house using streams almost exclusively (92\%) regardless of age and sex (Table 4). Privacy at bathing sites twas maintained by erecting thatehed screens around or slightly below a stream and diverting water along wooden spouting to create a crude shower inside the screened area. Virtually everybody bathed between 10 am and $6 \mathrm{pm}$.

T A B.I E IV

Water source used by individuals for bathing outside the house

\begin{tabular}{lrrrr}
\hline & \multicolumn{4}{c}{ Site of bathing } \\
\cline { 2 - 5 } Place & \multicolumn{2}{c}{ Stream } & \multicolumn{2}{c}{ Spring } \\
of residence & N. & $\%$ & N. & $\%$ \\
\hline Morro do Afonso * & 103 & 95.4 & 5 & 4.6 \\
Graviel & 80 & 94.1 & 5 & 5.9 \\
Riacho Seco & 32 & 78.0 & 9 & 220 \\
\hline
\end{tabular}

* Most individuals in Morro do Afonso bathe in a stream at a site 10-15 meters below its snail free spring of origin 
MOTA, E. \& SLEIGH, A. C. - Water-contact patterns and Schistosoma mansoni infection in a rural community in Noirthteast Brazil. Rev. Inst. Med. trop. Sto Paulo, 29(1): 1-8, 1987. 1):?

\section{Water-Contact and S. mansoni Infection}

Most individuals (104/141) aged less than 15 years bathed in streams (Table 5). The mean time spent for stream bathing was predictive of the prevalence of $\mathbf{S}$. mansoni infection: in. dividuals bathing more than 70 minutes per week in streams were significantly more likely $\left(\mathrm{X}^{2}=11.67 ; \mathrm{p}<0.01\right)$ to be infected $(82.5 \%$ prevalence) than those spending less than 70 minutes per week $(50.0 \%$ prevalence). The intensity of infection was also correlated to the amount of exposure to stream water; in children 5.14 years old there was a positive association between the individual egg count and the time spent bathing (Pearson correlation coeficient, $r=0.258 ; p<0.05)$.

T A B L E V

Stream bathing and $\mathbf{S}$. mansoni infection for individual aged less than 15 years old

\begin{tabular}{lcc}
\hline $\begin{array}{l}\text { Bathing } \\
\text { status }\end{array}$ & $\begin{array}{l}\text { Number with } \\
\text { stool exam. }\end{array}$ & $\begin{array}{l}\text { Prevalence of } \\
\text { S. mansoni }\end{array}$ \\
\hline $\begin{array}{l}\text { Do not bathe in } \\
\text { streams }\end{array}$ & 37 & 54.1 \\
$\begin{array}{l}\text { Bathe 1-70 minutes per } \\
\text { week in streams }\end{array}$ & 64 & 50.0 \\
$\begin{array}{l}\text { Bathe more than 70 } \\
\text { minutes per week in } \\
\text { streams }\end{array}$ & 40 & 82.5 \\
\hline
\end{tabular}

\section{DISCUSSION}

Reports from Puerto Rico (6), St. Lucia (3), Tanzania (13) and Ghana (4) have shown that the type and duration of individual water-contact is an excellent predictor of the prevalence and intensity of schistosomal infection. Our data on individuals resident in the Castro A1ves study area confirm this association. However, the most striking relationship here reported emerged at the household level of analysis and highlighted the extraordinarily focal nature of S. mansoni transmission within an endemic area.

Our data indicate that a key determinant of human infection is ecological. In Castro Alves nearly all residents used spring or stream water for bathing and domestic hygiene, thus, the prevalence and intensity of infection reflected the location of the household relative to the snail-free or snail colonized water sources. Residents of households on fazenda Morro do
Afonso presented a lower intensity of infection possibly due to the proximity of a safe water source, i.e. the snail-free spring, whereas those on fazendas Graviel and Riacho Seco were not so ecologically fortunate.

It has been suggested that poorly educated individuals in rural areas are necessarily in. discriminate in their water-contact and defaecation behaviour. However, our data indicate that, notwithstanding the extremely low level of formal education in the study area, neither defaecation nor water contact can be considered indiscriminate. The people make a considerable effort to obtain domestic drinking water from the cleanest source (the snail-free spring on Morro do Afonso) and only bathe at certain sites where privacy can be assured. It costs too much for most people to store enough rainwater to provide for all water needs throug. hout the year. The dispersal of houses along the hill crests makes it prohibitively expensive for individual residents to reticulate safe water supplies. Thus, regardless of their appreciation of dangers, the people at present have no choice for bathing and clothes washing other than using the nearest acceptable water body.

This study design did not allow us to elucidate the link between defaecation habits and S. mansoni transmission. However, it was ob. vious that for adults privacy and convenience were two major considerations in choosing a defaecation site. Future studies could well focus on the defaecation behaviour of the mobile, socially unaware and heavily infected group of children aged 9 to 15 years. If it could be confirmed that this group is responsible for most of the faecal contamination of the rural environment it would be appropriate to ensure that educational material stressing the need to defaecate below or far away from bathing and clothes washing sites, is designed specially for this age group. The installation of households latrines would not be expected to have much influence on transmission. The faecal contamination of the domestic environment in this rural area would be most unlikely to reach the distant bathing and clothes washing sites, although reducing faecal contamination of the domestic environment could have an impact in reducing the transmission of other infectious. and parasitic diseases. 
MOTA, E, \& SLEIGH, A. C. - Water-contact patterns and Schistosoma mansoni infection in a rural community in Northeast Brazil. Rev. Inst. Med. trop. São Paulo, 29(1): 1-8, 1987.

Repetitive use of community-based schistosomacidal treatment can lower the risk of heavy infections ${ }^{18}$ and a larga scale chemothe. rapy-oriented control program throughout Brazil is already underway ${ }^{12}$. It is predictable that the benefits of the control strategy to Brazilians resident in areas with endemic schistosomiasis will be considerable 20 . However, a permanent solution to schistosomiasis will depend on the availability of safe water supplies throughout the endemic zone 1,7-9,21. It will take many years of economic progress before rural peasants will have the resources to obtain safe domestic water supplies. Programs directed at lowering the cost of adequate supplies of safe water for rural Brazilians would be most appropriate. Possible alternatives include subsidizing the construction of large rain-water tanks, the development of a cheaper technique for building such tanks, or the reticulation of water supplies on a grand-scale throughout ru. ral Brazil.

\section{RESUMO}

Padrões de contato com a água e infecção por Schistosoma mansoni em comunidade rural do Nordeste brasileiro

Este estudo analisa a relação entre as características da infecção por $\mathbf{S}$. mansoni e o padrão de contato com água, os hábitos de higiene, a localização do domicilio, o nível educacional e as condições sócio-econômicas, em uma população definida residente na zona endêmica de Castro Alves, Bahia, Brasil. A área de estudo é típica de zonas rurais do Nordes. te, com relêvo acidentado e sua população dedica-se à lavoura não irrigada de fumo e man. dioca. Após o mapeamento da área e um in. quérito malacológico completo, foi aplicado um questionário para cada família com questões referentes às atividades de contato com água, tempo de exposição, condições de habitação e características sócio-econômicas. A prevalência e a intensidade de infecção por S. mansoni foram obtidas usando-se a técnica de Bell para a contagem de ovos nas fezes. A análise dos dados incluiu o cálculo de um índice de infeccão da família utilizando-se a contagem de ovos por grama de fezes de cada indivíduo. Poucas casas tinham instalaçōes sanitárias ou fonte de água para uso doméstico, entretanto, os há- bitos de defecação e de contato com água não eram indiscriminados, observando-se que os indivíduos dispenđiam esforço considerável em busca de água mais limpa para beber e para tomar banho, evitando defecar próximo às fontes de água. A propriedade da terra e o nível educacional não mostraram-se correlacionados com o indice de infecção. $O$ fator que pareceu influenciar a maior ou menor prevalência de infecção por $\mathbf{S}$. mansoni foi a localização das casas em relação à distância de uma fonte de ágụa não colonizada por Biomphalaria glabrata.

\section{ACKNOWLEDGMENTS}

This study was a collaborative project involving the Federal University of Bahia, The Fundação Oswaldo Cruz, and the Harvard School of Public Health. Field work was sup. ported by Antonio Celso Batista and Tomé Silva Oliveira. Technical support in the laboratory was provided by Vera Lúcia Menezes, Roberto Magalhães, and Tereza Maisk de Paiva. At Harvard the faculty and staff of the Department of Tropical Public Health furnished logistical, secretarial, and technical assistance; Dr. Thomas H. Weller provided administrative support and scientific advice throughout the study. Dr. Oto Oliveira and Dr. Reinaldo Rosa furnished vital local assistance.

\section{REFERENCES}

1. BARBOSA, F. S.; PINTO, R. \& SOUZA, O. A. - Conrol of Schistosomiasis mansoni in a small Northeast Brazilian community. Trans. roy. Soc. trop. Med. Hyg., 65: 206-213, 1971.

2. BARRETO, M. L.; FRANÇA, J. T.; MOTT, K. E.; LEHMAN, J. S. - Stability of faecal egg excretion in Schistosoma mansoni infection. Trans. roy. Soc. trop. Med. Hyg., 72: 181-187, 1978.

3. DALTON, R. R. - A sociological approach to the con. trol of Schistosoma mansoni in St Iucia. Bull. Wd. Hith. Org., 54: 587-595, 1976.

4. DALTON, P. R. \& POLE, D. - Water-contact patterns in relation to Schistosoma hematobium infection. Bull. Wld. Hith. Org., 56: 417-426, 1978.

5. FARROQ, M. \& MALJAH, M. G. - Patterns of Scoial and Religious water-contact activities in the Egypt-49 Bilharziasis Project Area. Bull. Wd. Hlth. Org., 35: 277-387, 1966.

6. JOBIN, W. R. \& RUIZ-TIBEN, F. - Bllharria and patterns of human contact with water in Puerto Rico. Bol. Asoc. med. P. Rico, 60; 279-284, 1968. 
MOTA, E. \& SLEIGH, A. C. - Water-contact patterns and Schistosioma mansoni infection in a rural community in Northeast Brazil, Rev. Inst. Med. trop. São Paulo, 29(1): 1-8, 1987.

7. JORDAN, P. - Epidemiology and control of schistosomiasis. Brit. met. Bull., 28: 55-59, 1972.

8. JORDAN, P.; WOODSTOCK, I.; UNRAU, G. O. \& COOK, J. A. - Control of Schistosoma mansoni transmission by provision of domestic water supplies. Bull. Wld Hith. Org., 52: 9.20, 1975.

9. JORDAN, P.; UNRAU, G. O.; BARTHOLOMEW, R. K.; COOK, J. A. \& GRIST, E. - Value of individual household water supplies in the maintenance phase of schistosomiasis control programme in St Lucia, after chemotherapy. BulI. Wld. Hlth. Org., 60: 583-588, 1982.

10. LEHMAN, J. S.; MOTT, K. E.; SOUZA, C. A. M.; LEBOREIRO, O. \& MUNIZ, T. M. - The associaton of Schistosomiasis mansoni and proteinuria in an endemic area. Amer. J. trop. Med. Hyyg., 24: 616-618, 1975.

11. LERMAN; J. S.; MOTT, K. E.; MORROW, R. H.; MUNIZ, T. M. \& BOYER, M. H. - The intensity and effects of infection with Schistosoma mansoni in a rural community in northeast Brazil. Amer. J. trop. Med. Hyg., 25; 552-562, 1976.

12. MACHADO, P. A. - Brazil's special schistosomiasis control program: the model. Bull, Wld. Hoth. Org. 13: $33-45,1979$

13. McculloUg.H, F. S.; EYaKUZE, V. M.; MSINDE, J. \& NDITI, H. - Water resources and bilharziasis transmission in the Misungwi area, Mwanza District, North-east Tanzania. E. Afr. med. J., 45: 295-308, 1968.

14. MTCheisON, E. H. \& DuBOIS, L. - Susceptibility of Bahia populations of Biomphalaria glabrata to an allopathic strain of Schistosoma mansoni. Amer. J. trop. Mei. Hyg., 27: 782.786, 1978.

15. MTCHELSON, E. H. \& MOTA, E. - Malacological ob. servations bearing on the epidemiology of schistosomiasis in a rural Bahian community. Rev. Inst. Med. trop. S. Paulo, 24: 75-82, 1982.
16. MOTT, K. E.; LEHMAN, J. S.; HOFF, R.; MORROW, R. H.; MUNIZ, T. M.; SHERLOCK, I. \& DRAPER, C. C. - PUGLIESE, C.; GUIMARAES, A. C. The epidemiology and household distribution of seroreactivity to Trypanosoma cruzi in a ruxal community in northeast Brazil. Amer. J. trop. Med. Hyg., 25: 552-562, 1976.

17. PIMENTEL, D.; GERHARDT, C. E.; WHLIAMS, E. R.; WHITE JR., P. C. \& FERGUSON, F. F. - Aspects of schistosomal endemicity in three Puerto Rican Watersheds. Amer. J. trop. Med. Hyg., 10: 523-529, 1961.

18. SLEIGF, A. C.; MOTT, K. E.; FRANÇA, J. T.; MUNIZ, T. M.; MOTA, E. A.; BARRETO, M. L,; HOFF, R.; MAGUIRE, J. H.; LEFMMAN, J. S. \& SHERLOCK, I. - A three year follow-up of chemotherapy with oxam. niquine in a Brazilian community with endemic Schistosomiasis mansont. Trans, roy. Soc. trop. Med. Hyg., 75: 234-238, 1981.

19. SLEIGH, A.; HOFF, R.; MOTT, K. E.; BARRETO, M. L.; PIVA, T. M.; PEDROSA, J. S. \& SHERLOCK, I. - Comparison of filtration staining (Bell) and thick smear (Kato) for the detection and quantitation of Schistosoma mansoni eggs in faeces. Trans, xoy. Soc. trop. Med. Hyg., 76: 403-406, 1982.

20. SLEIGH, A. C.; MOTT, K. E.; HOFF, R.; BORRETO, M. L.; MOTA, E. A.; MAGUIRE, J. H.; SHERLOCK, I. \& WELLER, T. F. - Three-year prospective study of the evolution of Manson's schistotomiasis in North east Brazil. Lancet, 2: 63-66, 1985.

21. UNRAU, G. O. - Individual household water supplizs as a control measure against schistosoma mansoni. A study in rural St Lucia. Bull. Wld. Hith. Org., 52: I-8, 1975.

Recebido para publicação em 29/1/86. 